\title{
SYNERGISTIC ANALYSIS OF THE HISTORICAL AND CULTURAL DEVELOPMENT OF INDUSTRIAL ARCHITECTURE
}

\author{
Yury Nikitin ${ }^{1}$, Olga Tsepilova ${ }^{2 *}$ \\ ${ }^{1}$ Emperor Alexander I St. Petersburg State Transport University \\ Moskovsky pr., 9, Saint Petersburg, Russia \\ ${ }^{2}$ Saint Petersburg State University of Architecture and Civil Engineering \\ Vtoraja Krasnoarmeyskaya st., 4, Saint Petersburg, Russia \\ * Corresponding author: tsepilova.art@gmail.com
}

\begin{abstract}
Introduction: By determining the importance of industrial architecture as an object of cultural value, it is possible to identify the new principles for preserving the identity of a historical location. Purpose of the study: We aim to research different periods in the formation of the architectural and spatial layout of industrial buildings and structures; to determine which principles are applied when the buildings and structures are adapted for reuse. Methods: In this article, we use a synergistic approach to studying the specifics of the historical and cultural development of industrial architecture. Results and discussion: After analyzing the target of our study as a self-organizing system, as well as taking a look at its relationship with various structures, depending on the nonlinearity of the ongoing processes, we came to the conclusion that the emergence of different stylistic trends in industrial architecture can be viewed through the lens of significant historical periods, or bifurcations, which were the result of human activity in the past and would influence the functional development of the resulting space in the future. This approach reflects sociocultural needs and unlocks the potential for reusing historically significant industrial sites in various ways.
\end{abstract}

\section{Keywords}

Synergistic approach, industrial architecture history, time-space relationship, genius loci.

\section{Introduction}

The architectural heritage of large cities is represented by a wide range of different architectural movements and types of buildings. The time-space relationship is reflected in the variety of style combinations from different eras; these are inextricably linked to the growth of urban space, as well as to compositional techniques, form-making methods, the technological capabilities of a certain time period, and the boldness of architectural thought. In the life of society, buildings and structures act as a means of communication, reflecting certain traditions, customs, experiences, ideas, and feelings, especially when several generations engage in dialog at once. This is what informed the Washington Charter, which defines the principles and methods necessary for the conservation of historic towns and urban areas that help to "promote the harmony of both private and community life in these areas and to encourage the preservation of those cultural properties, however modest in scale, that constitute the memory of mankind" (ICOMOS, 2021).

Stylistic features in architecture arose and developed not only sequentially, but also nearly simultaneously, complementing each other as a result of the interaction (Kholodova, 2010). Once Sigfried Giedion said that in order to understand the true nature of a certain period in the development of architecture, it is not enough just to study public buildings, representative residences, and monuments. In the course of historical events, it was the construction of modest utilitarian buildings that led to the decisive development of new architectural techniques and opportunities (Morozova, 2008).

Industrial architecture is subjected to historical process development just as much as the construction of administrative, religious, cultural, public, and residential buildings. Industrial architecture originates simultaneously with the urban community. It grows and transforms together with the city, becomes firmly woven into the urban structure, and has a significant impact on its changes, in addition to reflecting the social environment of its time. The development of this type of architecture is driven by the emergence of more and more new technical, technological, and economic capabilities. As the relationship between humankind and the production machine evolves, the development timeline of architectural and spatial forms in industrial architecture evolves as well (Myslin, 1936). The dynamics of this development can be considered using a synergistic approach.

\section{Methods}

The synergistic approach is a set of different principles that are based on considering the object of the study as a self-organizing system. Synergetics considers a certain relationship of a group of structures and defines it as a state that arises as a result of many options for the development of fundamental systems, 
which evolve progressively due to the nonlinearity of internal states and processes (Zhuikov, 2011).

The main principles of the synergistic approach are as follows:

- architectural sites must be studied as systems, which are: developing; open (the openness of a site characterizes its ability to exchange information, energy, etc.); complex; and nonlinear (nonlinearity determines the presence of various development variations that depend on random external or internal influences);

- the self-organization of these systems is initially chaotic and unstable, which leads to the formation of possible fluctuations, or oscillations, deviating from the average values of the processes typical of these systems;

- there are certain alternative ways of system development, which are formed at the points of bifurcation; this creates a choice of direction for further development;

- the future development of the system shapes its actual state, in which attraction factors (attractors) act as an end in itself, determining the direction of the system development (Nekrasova and Nekrasov, 2009).

The synergistic approach is based on the idea of the functional dependence of the past on the present, and the present on the future (Kholodova, 2010). Thus, if we consider the development of architecture as the core of synergistic analysis, we will be able to perceive the emergence of different stylistic directions and types, resulting from historical development, as a synthesis of the interaction between various elements and the methodological apparatus of the space self-organization theory. It is also useful to take into account the approach of Moses Kagan, who studies the highest form of a selforganization process, resulting in the development of an anthropocentric sociocultural system. The

1)

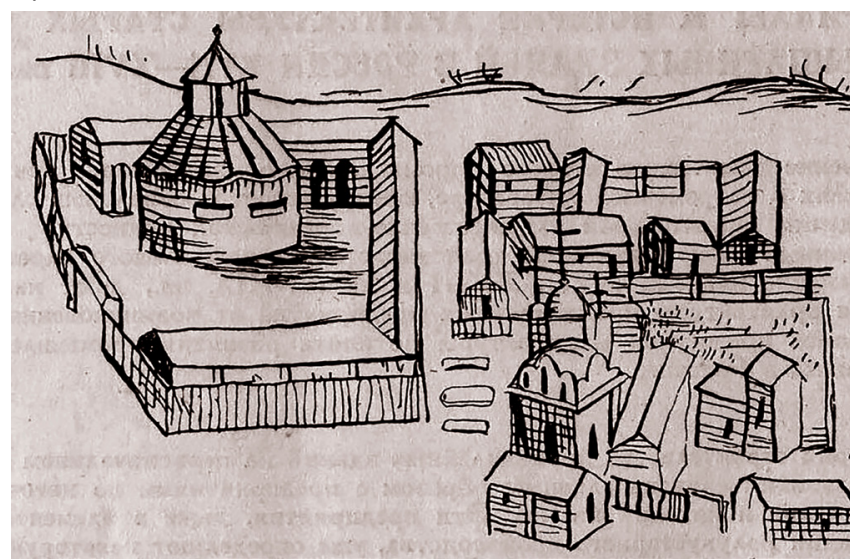

complexity of these structures is multiplied by the complexity of development that occurs as a result of conscious human activity (Mamutova, 2012).

\section{Results and Discussion}

In the course of historical events, there were three bifurcations, or turning points that influenced the change in the perception and actualization of industrial architecture from the point of view of a more figurative spatial perception (Figs. 1, 2):

1 - a massive transition from manual labor (Fig. 1 ) to mechanical labor in the $18^{\text {th }}$ and $19^{\text {th }}$ century, considered one of the most important events in the history of mankind that shaped the world we live in today (Fig. 2);

2 - the development of continuous flow-line, electricity-powered machine production at the end of the $19^{\text {th }}$ and the beginning of the $20^{\text {th }}$ century (Fig. 3);

3 - the digital revolution of the late $20^{\text {th }}$ and early $21^{\text {st }}$ century (Fig. 4).

As a result of three industrial revolutions, spurred on by the changes in socioeconomic relations, scientific and technological progress, and urbanization, many production processes have been reconsidered and transformed. In most cases, this has led to the withdrawal of industrial sites to city outskirts; and in some cases, industrial production has completely lost its relevance and industrial sites have been abandoned. Thus, "gray spots" or "gray belts" of abandoned industrial architecture have formed among the historical buildings of many cities. This creates possible fluctuations and an unfavorable environment that affects the emotional state of the local residents. The influence of the time factor also has an impact, leading to the gradual destruction of buildings and the lack of security. Nevertheless, all of the above creates a special appeal for creative youth (Voznyak, 2018).

If we are aware of the various properties of the architectural and planning layout of industrial

2)

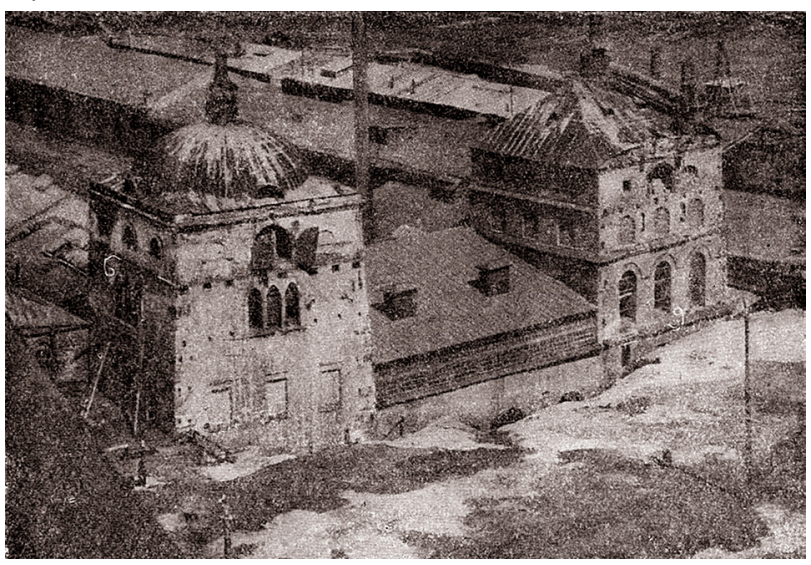

Figures 1,2 . Development of industrial architecture in the $17^{\text {th }}$ through $19^{\text {th }}$ century:

1) Industrial architecture of the $12^{\text {th }}$ and $13^{\text {th }}$ century, before the First Industrial Revolution, as exemplified by the Cannon Foundry Yard in Neglinnaya Street. Moscow plan of 1610 (Podolsky, 1936)

2) Blast-furnace building of the Nevyansk factory, late $18^{\text {th }}$ century (Podolsky, 1936) 
3)

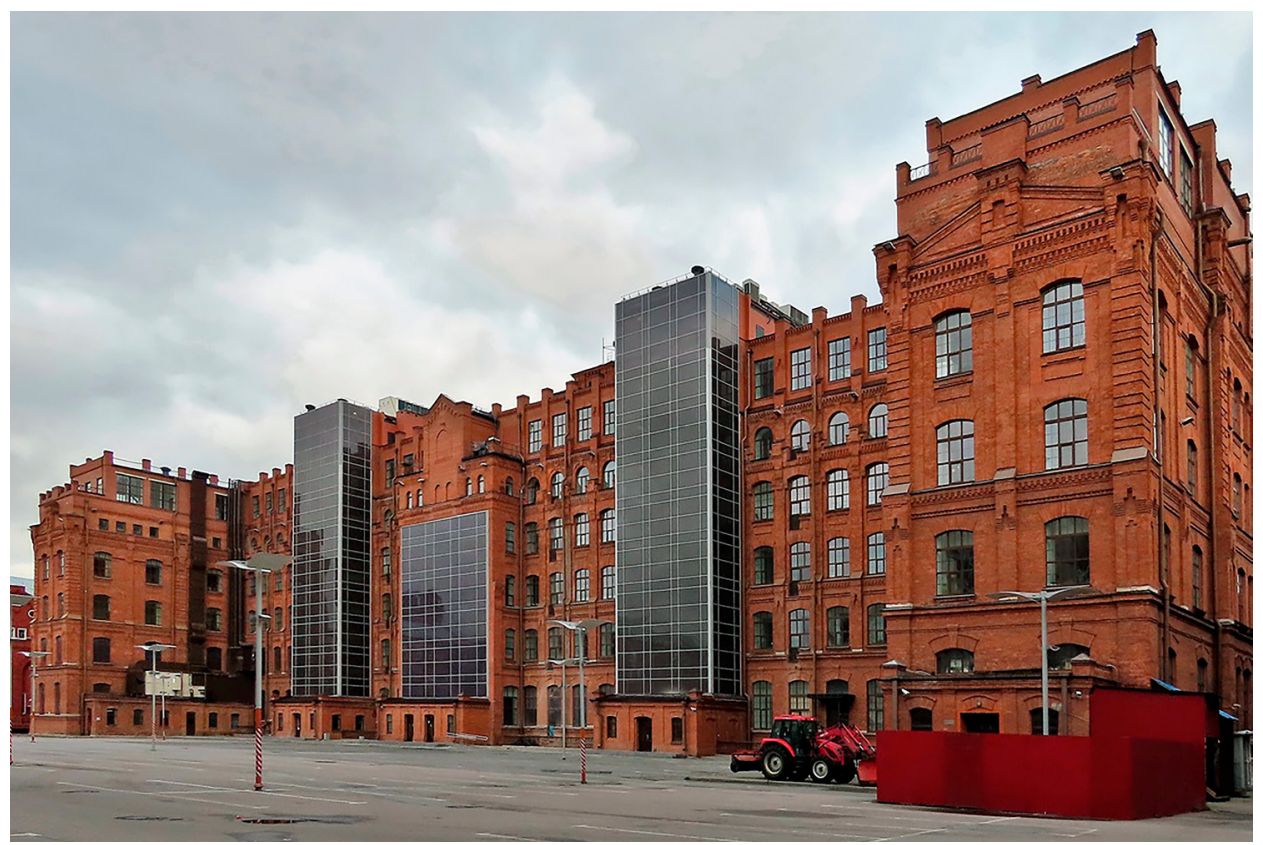

4)

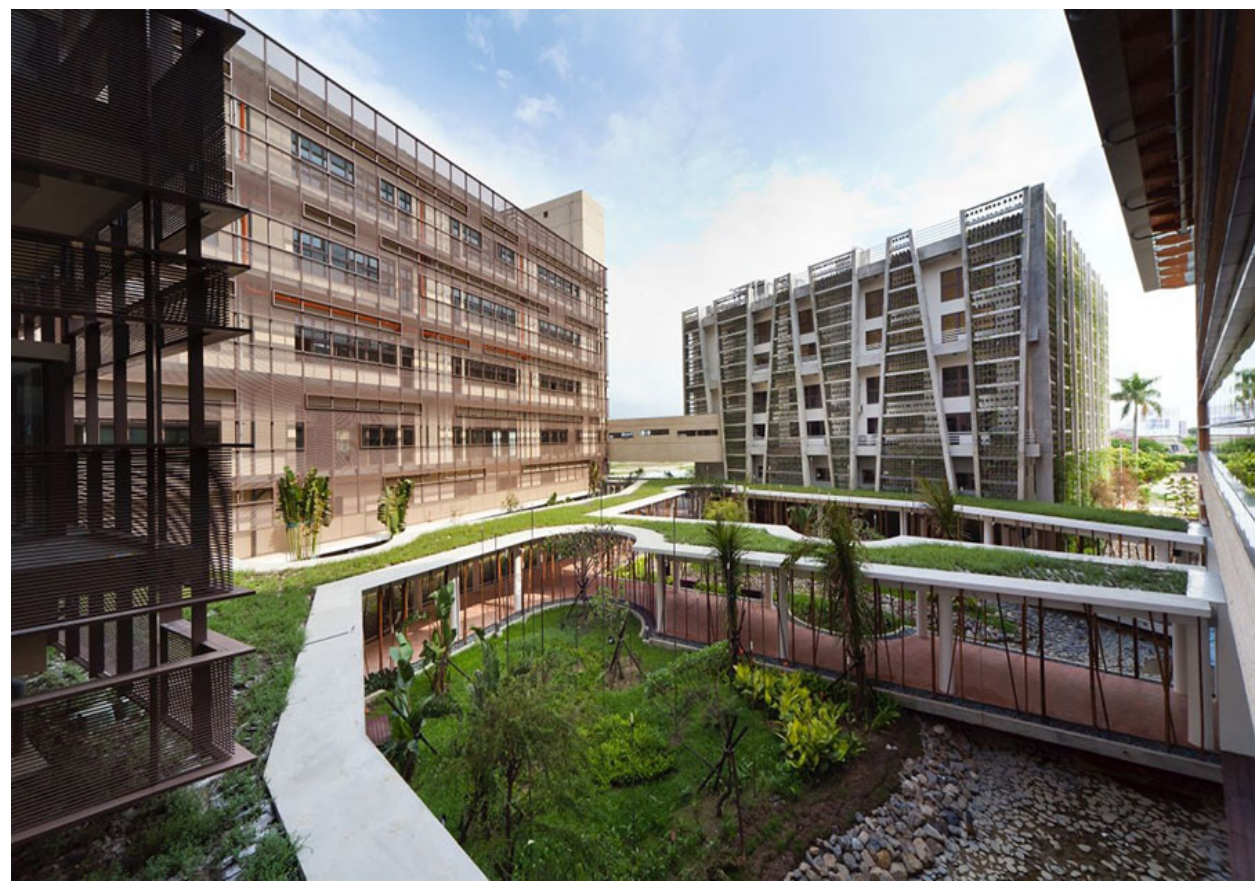

Figures 3, 4: Development of spatial and architectural solutions for industrial complexes over the course of historical events from the $19^{\text {th }}$ through the $21^{\text {st }}$ century:

3) Nevskaya paper-spinning manufactory. St. Petersburg, Russia, 1895 (source: Citywalls, 2020)

4) Innovative industrial center. Chiayi, Taiwan, 2011. Photo @ Bio-architecture Formosana (source: architime.ru)

architecture spaces, of the requirements for their development, and of the laws conducive to their self-organization, we will be able to manage the existing system more conscientiously and approach the issues of its future use more reasonably. Modern approaches to the preservation of abandoned industrial buildings account for various influence factors and the perception of incoming information.

The formation of semantic unity between the existing historical environment, the selected site and the human user's demands follows certain principles in accordance with aesthetic shaping and practical application.

For a synergistic analysis of reusing abandoned industrial architecture, the backbone factors are:

- the human user acting as an attractor, and the activity of this user, which informs a specific request for shaping a new internal space in the existing environment;

- the historical significance of the selected site;

- the sociocultural significance of the site's reuse, as well as its possible fluctuations; 
- the space-time relationship as a source of information, that is, the spatial layering of historical development in the past, present, and future (Shevelev and Stupak, 2017).

The existing experience in adapting abandoned industrial buildings fully highlights the relevance of this issue. The analysis of works on this subject has helped us trace the co-evolution of humankind and architecture, while also making it possible to draw up a rough scale of priority directions for the reuse of abandoned industrial culture sites. The shifts in functional usage types tend to "undulate" from mass consumption to individual use and back again. The multiple existing approaches to functional usage directly depend on temporal, geographical, historical, cultural, economic, environmental, and social factors. We could say that one of the main approaches here is the typological approach, which characterizes the purpose of the site that is being adapted: work, housing, or leisure (Gelfond, 2011). The current link between the site and the environment, the financial capabilities of the customer, and the specific sociocultural needs of the local community help narrow down the functional content. This gives us a more systemic understanding of the prospects for reusing abandoned industrial sites while respecting the location's historical significance.

Synergistic Analysis of Industrial Architecture Reuse

The building's original function once determined its architectural and spatial layout, and in the future, the new function will be affected by the temporal changes, accommodating for the existing form. This trend becomes evident in the re-purposing of the abandoned Eveleigh Rail Yards in Sydney, Australia (Figs. 5-8).

5)

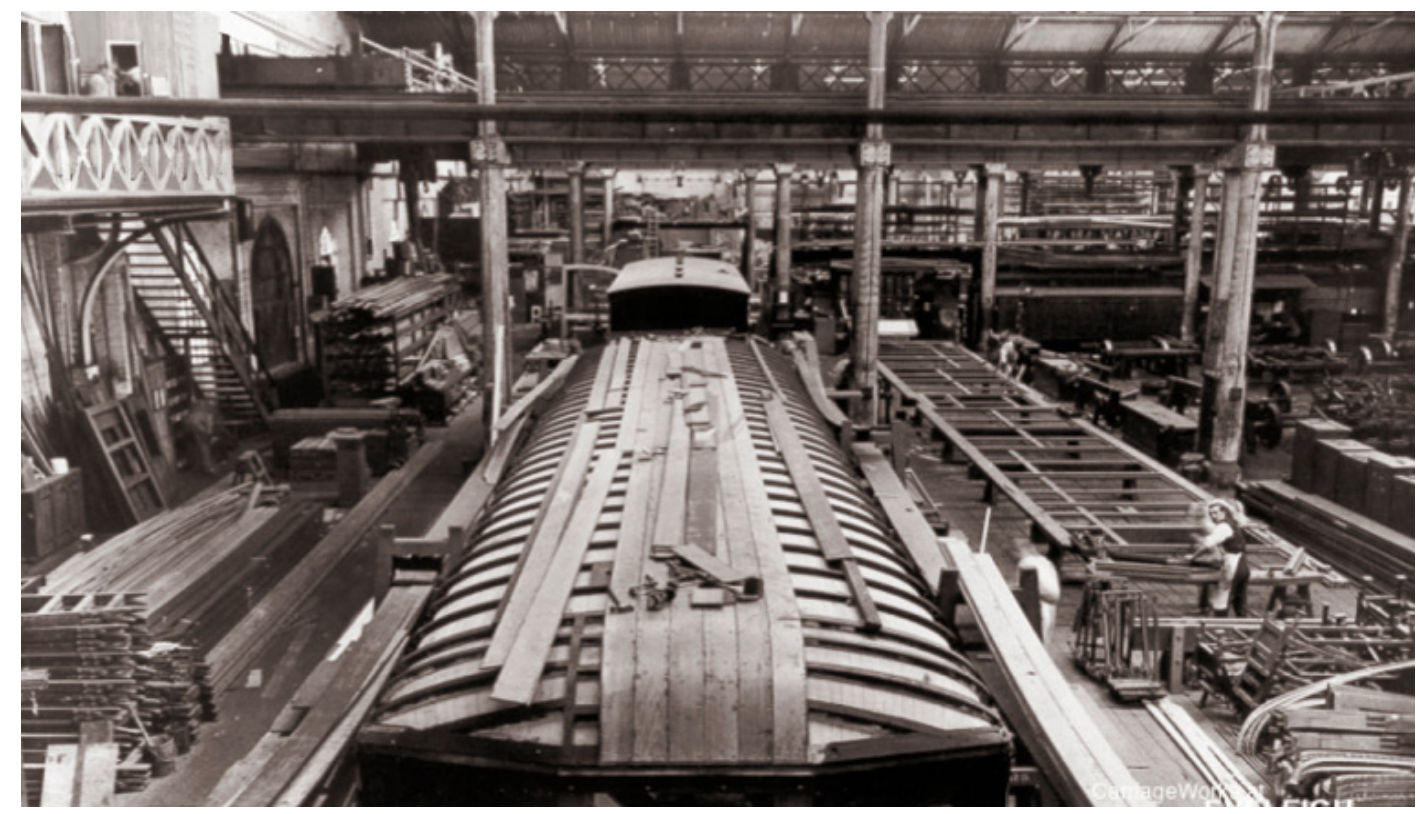

6)

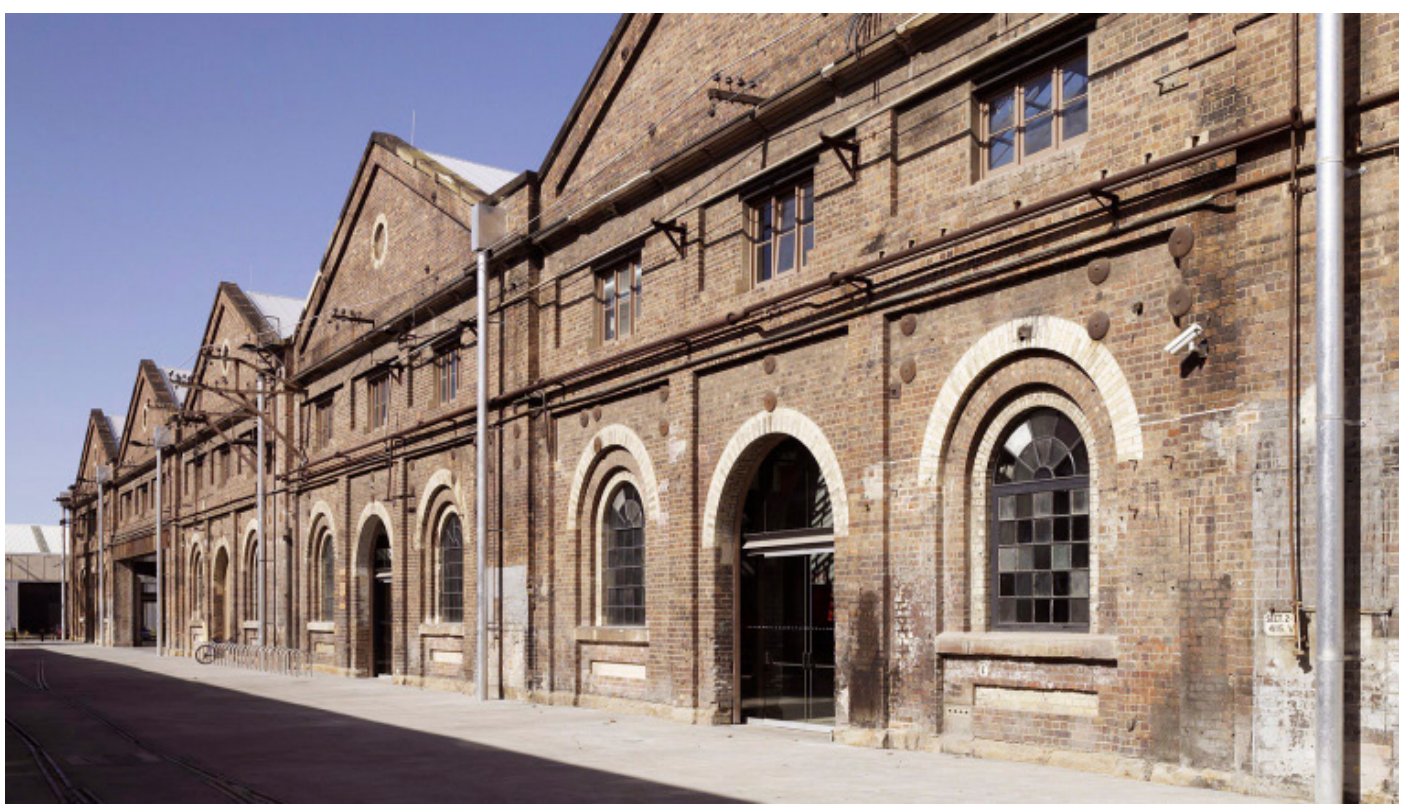


7)

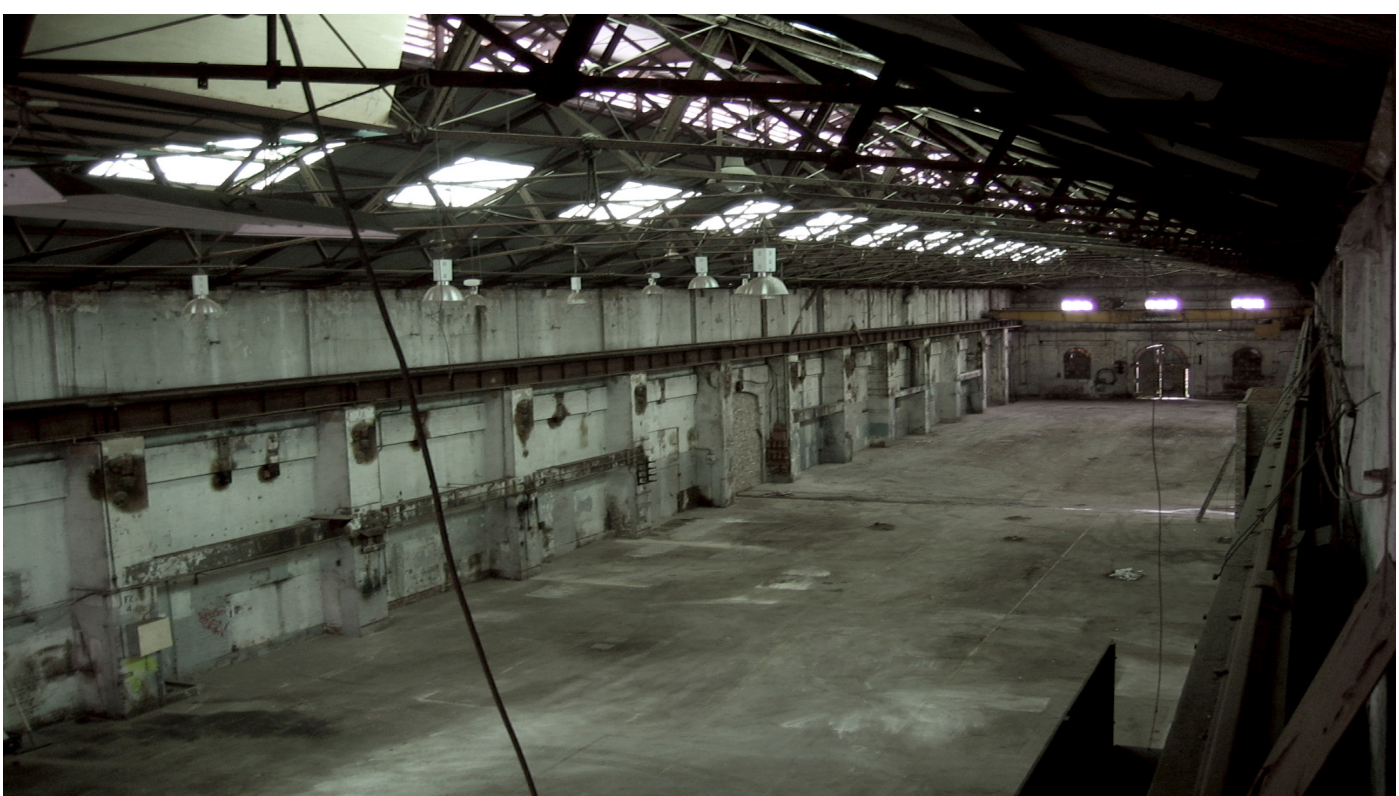

8)

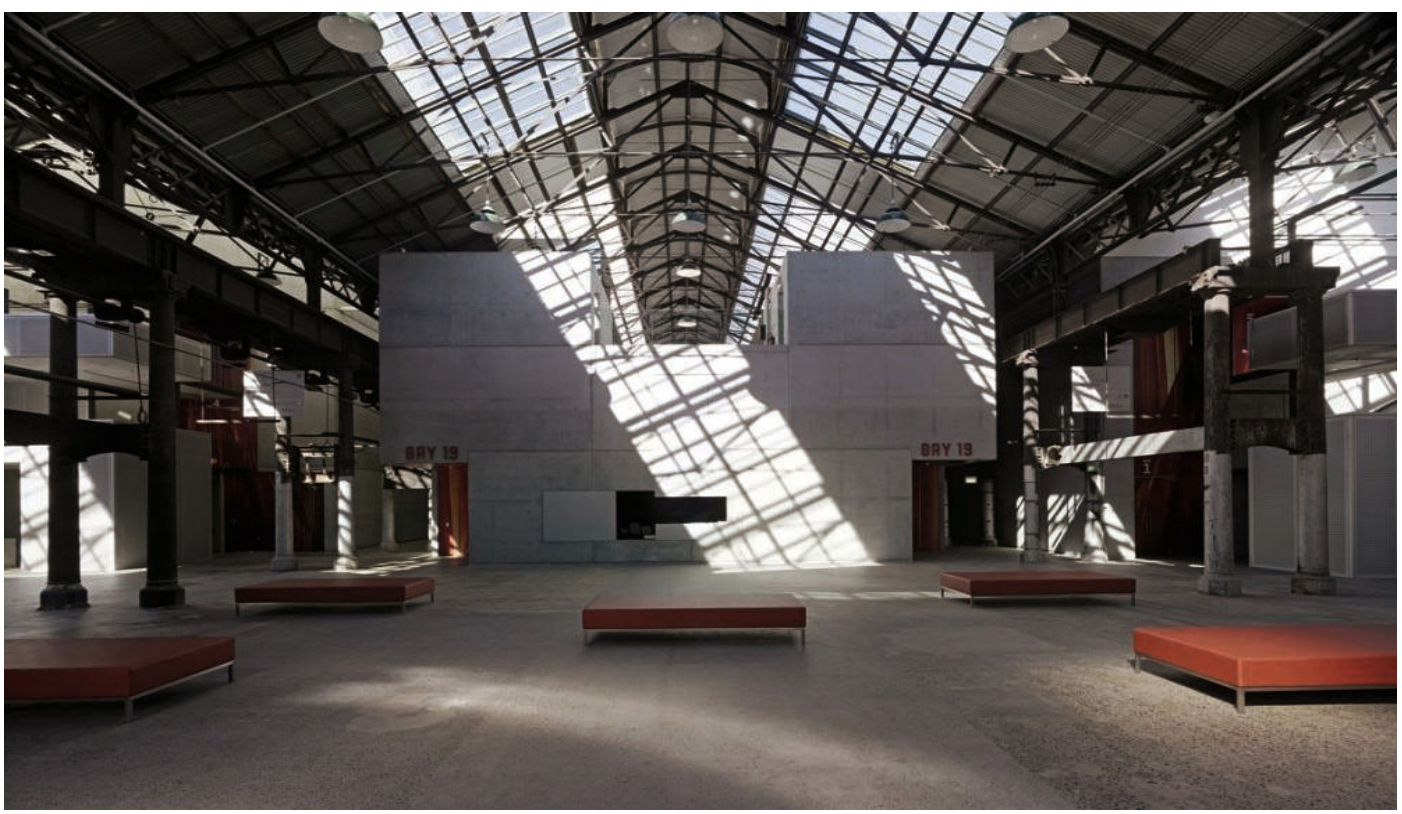

Figures 5-8: Transformation of the abandoned Eveleigh Rail Yards, built in Sydney, Australia, in the 1880s, into Carriageworks, a modern center for performing arts (theater, experimental dance, acrobatic shows)

5) Carriageworks of the Eveleigh Railway Complex (circa 1880s, designed by George Cowdry), State Rail Authority Records, New South Wales State Archives and Records (source: Heritage Council of Victoria, 2021)

6) Carriageworks of the Eveleigh Railway Complex (photo by Michael Nicholson)

7) Carriageworks pre-construction (source: OCP Architects, 2021)

8) Carriageworks performing arts center in Sydney, Australia (circa 2006, photo by Michael Nicholson)

Time and motion "burst into" the integral structure and impose "new demands" (Gelfond, 2011). One of the earliest types of re-purposing industrial architecture was the creation of museum and exhibition spaces. The three-dimensional planning features of this type of architecture had a suitable unique compositional layout, large open spaces, and an already established transport infrastructure, perfect for meeting the consumer demand. Urban planning and economic aspects influenced the subsequent stages of the sites' adaptation, which led to the development of public and business venues, shopping centers, and residential spaces. Based on the "pattern language" theory (Mehaffy, 2012), which Karasev and Denisenko discuss in their paper, Reorganization of Industrial Territories and Architectural Objects with Considering Adaptive Processes, the specific feature, in this case, is the 
openness to transformation. This allows for switching between several different concepts, depending on consumer demand, and thus encourages the trend of combining the business, public, and housing functions (Karasev and Denisenko, 2020). Adaptive reuse is a promising area in the development of architecture, as it helps to bring abandoned industrial buildings back to life and revive the genius loci.

In this article, we use the basic principles of the synergistic approach as a basis for predicting which functional purpose abandoned industrial architecture is most likely to be reused for. The current state of the cultural and social consciousness is determined by the interconnection between the chaotic environmental, political, and economic developments, the "information explosion", the changes in the nature of human labor, and the scientific and technological progress. For a more accurate prediction of re-purposing the industrial sites and eliminating the fluctuation probability, it is particularly important to be aware of the past and the present. As we build upon an aggregate set of the main principles for choosing the new function, including urban significance, historical importance, conservation status, spatial planning layout, and sociocultural impact (Bessarabova and EvtushenkoMulukaeva, 2019), we should not lose sight of the projected transformations in society. In this case, the openness of complex nonlinear systems forming the site that is being used is characterized by a multitude of functions and the modularity of the future spatial layout. From the synergistic standpoint, it is worth considering the mutual links between the new functions and their subsequent impact on the existing transport infrastructure, the environmental management, and the impact on industrial architecture safety levels and on the community's social life. The actual progress of managing the site's functions will contribute to the subsequent choice of alternatives for developing the spatial transformation and filling the site with innovative content.

The evolution of industrial architectural styles is pushing the boundaries of re-purposing industrial sites. The architectural and spatial features of adapting abandoned industrial buildings and structures are shaped by the direct interaction between the old, i.e. the historical structure, and the new, i.e. the new target function. The new functional planning and compositional solution for arranging the internal layout should fit harmoniously into the existing environment. Re-purposing the selected site may have different degrees of impact on the integrity of its historical design. This is why the extent to which the site's existing structure is going to be physically disrupted is determined by the preservation of its cultural significance and the revival of the genius loci (Bloszies, 2013). Regular fluctuations in sociocultural needs and economic opportunities continually support the claim that re-purposing historically significant industrial architecture is highly relevant.

\section{Conclusions}

The modern adaptation of abandoned industrial complexes helps to take a fresh look at the historically formed urban structure, as well as renew the interest in local history and improve the city's economic, cultural, and social wellbeing. The preservation of the value of abandoned industrial factories and plants is a suitable response to the needs of modern human life. At the same time, the authenticity of the site is preserved and expressed both through the interconnection of the site's internal space and the environment, and through the figurative interaction between modern city life and historical genius loci. Such a synthesis allows the visitor to become part of a historical landmark, bringing it back to life and filling it with a new function. In the context of synergistic analysis, it is by adapting abandoned industrial architecture to meet modern needs and by using the opportunities of today that we create all kinds of fluctuations, which depend on the site's past functional purpose and will affect its new use in the future. The predicted transformations of modern society are already affecting the relationship between the historically formed structure and the future existence of its new iteration. 


\section{References}

Bessarabova, Y. I and Evtushenko-Mulukaeva, N. M. (2019). Architectural adaptation of industrial enterprise to new function. Engineering and Construction Bulletin of the Caspian Region, 2, pp. 28-33.

Bloszies, C. (2013). Old buildings, new designs: architectural transformations. New-York: Princeton Architectural Press, $144 \mathrm{p}$.

Heritage Council of Victoria (2021). Industrial heritage. Case studies. Carriageworks. [online] Available at: https://heritagecouncil.vic.gov.au/wp-content/uploads/2014/08/Carriageworks-Case-Study.pdf [Date accessed March 10, 2021].

Citywalls (2020). Complex of buildings of Nevskaya paper-spinning manufactory. Building of factory No. 2. [online] Available at: https://www.citywalls.ru/house9288.html [Date accessed November 27, 2020].

Eveleigh Stories (2021). Evolution of Eveleigh - the railway workshops. [online] Available at: https://eveleighstories.com. au/stories/evolving-eveleigh/evolution-eveleigh-railway-workshops [Date accessed March 10, 2021].

Gelfond, A. L. (2011). Architectural typology in the aspect of the life cycle of a building. ACADEMIA. Architecture and Construction, 2, pp. 40-47.

ICOMOS (2021). Washington Charter 1987. International Charter for the Conservation of Historic Towns and Urban Areas. [online] Available at: http://icomos.org.ru/images/docs/1987_Mezhdunarodnaya\%20hartiya\%20po\%20ohrane\%20gorodov.pdf [Date accessed January 4, 2021].

Karasev, R. O. and Denisenko, E. V. (2020). Reorganization of industrial territories and architectural objects with considering adaptive processes. News of the KSUAE, 2, pp. 177-186.

Kholodova, L. P. (2010). Concepts of modern theory of architecture. Architecton: Proceedings of Higher Education, 3. [online] Available at: http://archvuz.ru/2010_3/1 [Date accessed January 14, 2021].

Ledeneva, N. (2021). Top-10 unusual industrial buildings. [online] Architime.ru. Available at: https://www.architime.ru/specarch/top_10_industrial_architecture/factory.htm [Date accessed January 1, 2021].

Mamutova, Kh. E. (2012). Synergistic analysis of the culture dynamics. Culture of the Peoples of the Black Sea Region, 244, pp. 220-223.

Mehaffy, M. (2012). Tactical urbanism using "pattern language” toolkits. [online] Available at: https://www.cnu.org/sites/ default/files/tactical_urbanism_with_pattern_language_toolkits-mehaffy.pdf [Date accessed February 17, 2021].

Morozova, Ye. B. (2008). Industrial architecture: what will happen tomorrow? Technical Regulation, Standardization and Certification in Construction, 5, Part 1, pp. 159-166.

Myslin, V. A. (1936). Architecture of production floors. In: Aleksandrov, A. Ya. (ed.) Problems of Architecture: Collection of Materials, Vol. 1, Book 2. [online] Tehne.com. Available at: http://tehne.com/event/arhivsyachina/v-myslin-arhitektura-proizvodstvennyh-cehov-1936 [Date accessed September 14, 2020].

Nekrasova, N.A. and Nekrasov, S. I. (2009). Philosophy of science and technology: a thematic reference dictionary. Moscow: MIIT, $424 \mathrm{p}$.

OCP Architects (2021). Eveleigh Carriageworks. [online] Available at: https://ocp.net.au/eveleigh-carriage-works/ [Date accessed March 10, 2021].

Podolsky, R. P. (1936). References for the history of $17^{\text {th }}-18^{\text {th }}$ century industrial architecture in Russia. In: Aleksandrov, A. Ya. (ed.) Problems of Architecture: Collection of Materials, Vol. 1, Book 2. [online] Tehne.com. Available at: http://tehne. com/event/arhivsyachina/r-p-podolskiy-materialy-k-istorii-arhitektury-staryh-promyshlennyh-zdaniy-v-rossii-xvii-xviii-vekov [Date accessed October 2, 2020].

Shevelev, V. P. and Stupak, E. Yu. (2017). Time as the basic factor of development of urban space. Architectural Research, 4, pp. 58-62.

Voznyak, E. R. (2018). The problem of abandoned buildings and objects. In: Modern Problems of History and Theory of Architecture. Proceedings of the 4th All-Russian Scientific and Practical Conference. Saint Petersburg: Saint Petersburg State University of Architecture and Civil Engineering, pp. 40-45.

Zhuikov, S. S. (2011). The synergetic approach to researches of architectural process. Akademicheskij Vestnik UralNIIproekt RAASN, 3, pp. 47-52. 


\title{
СИНЕРГЕТИЧЕСКИЙ АНАЛИЗ ИСТОРИКО-КУЛЬТУРНОГО РАЗВИТИЯ ПРОМЫШЛЕННОЙ АРХИТЕКТУРЫ
}

\author{
Юрий Анатольевич Никитин ${ }^{1}$, Ольга Павловна Цепилова 2* \\ 1 Петербургский государственный университет путей сообщения Императора Александра I \\ Московский пр., 9, Санкт-Петербург, Россия \\ ${ }^{2}$ Санкт-Петербургский государственный архитектурно-строительный университет \\ 2-ая Красноармейская ул., 4, Санкт-Петербург, Россия \\ *E-mail: tsepilova.art@gmail.com
}

\begin{abstract}
Аннотация
Определение значимости промышленной архитектуры как объекта, имеющего культурную ценность, поможет выявить наиболее перспективные направления его функционального перепрофилирования с сохранением идентичности исторического места. Цель исследования: Изучение периодизации формирования архитектурно-пространственной организации индустриальных зданий и сооружений как модели самоорганизующейся системы, а также определение различных принципов их адаптации для повторного использования. Методы: В данной статье специфика историко-культурного развития промышленной архитектуры рассматривается с помощью синергетического подхода. Результаты и обсуждение: Анализируя изучаемый объект как самоорганизующуюся систему, его взаимосвязи с различными структурами в зависимости от нелинейности происходящих процессов, мы пришли к выводу, что появление разных стилистических направлений в промышленной архитектуре можно рассмотреть через призму знаковых исторических периодов - бифуркаций, которые стали результатом деятельности человека в прошлом и повлияли на функциональное развитие создаваемого пространства в будущем. Этот подход отражает социально-культурные потребности и раскрывает потенциал различных возможностей повторного использования исторически значимых промышленных объектов.
\end{abstract}

\section{Ключевые слова}

Синергетический анализ, история развития промышленной архитектуры, взаимосвязь времени и пространства, память места. 